\title{
Practical testing of Scots pine cutting propagation - a joint Metla-Skogforsk-Silava project
}

\author{
Karl-Anders Högberg ${ }^{1}$, Jörgen Hajek ${ }^{2}$, Arnis Gailis ${ }^{3}$, Niina Stenvall ${ }^{4}$, Inga Zarina ${ }^{3}$, Satu Teivonen ${ }^{4}$, Tuija Aronen $^{5^{*}}$ \\ From IUFRO Tree Biotechnology Conference 2011: From Genomes to Integration and Delivery \\ Arraial d Ajuda, Bahia, Brazil. 26 June - 2 July 2011
}

Testing of candidates as clones would greatly benefit breeding of Scots pine (Pinus sylvestris L.), but has not been applied because of vegetative propgation of the species is difficult. With a common interest in Scots pine breeding, forest research institutions from Sweden, Finland, and Latvia (Skogforsk, Metla, and Silava, respectively) joined in a collaborative project to develop pine cutting propagation for breeding purposes. The main objective of this effort was to find protocols for sufficient shoot production, and at the same time, maintain a high rooting response. Secondly, the aim was to increase the knowledge on the influence of different rooting agents, watering regimes and substrates on the rooting of cuttings.

From Finland and Latvia, respectively, 15 full-sib families from parents with high breeding values were included. From Sweden, 15 families from each of two research stations, one northern and one southern, were included. These sets of the families were used locally. Another collection of five families was shared among the participants, which means that 5 families extra were included at each location.All donor plants were pruned according to the same principles. However, the timing of the pruning varied in the five propagation models tested:

A. One-year-old donor plants pruned to yield $2 \mathrm{x}$ winter cuttings / 4-year method

B. One-year-old donor plants pruned to yield winter cuttings and late summer cuttings/ 3-year method

C. "Turbo line" i.e. one-year-old donor plants pruned $2 \mathrm{x}$ cuttings in one year/2-year method
D.One-year-old donor plants pruned to yield $2 x$ late summer cuttings/ 3-year method

E. Two-year-old donor plants pruned to yield winter cuttings/ 4-year method

According to the results, the average production of cuttings with propagation models including two harvests in consecutive years on the same donor plant can be predicted to be 10-15 cuttings per a donor plant, with a substantial variation among families and donor plants. Even though rooting responses above $50 \%$ can be achieved, this could not be repeated for a large number of propagations. The generally low and erratic rooting response leads to conclusion that the project was unsuccessful in developing improved and reliable protocols for Scots pine cutting propagation. However, a propagation model enabling two harvests on a 1-year-old donor plant within the same year is a promising option but needs further studies.

More detailed information on the project and its results is available at: http://www.metla.fi/julkaisut/ workingpapers $/ 2011 / \mathrm{mwp} 198 . \mathrm{htm}$

\section{Author details \\ ${ }^{1}$ Skogforsk, Ekebo, Sweden. ${ }^{2}$ Skogforsk, Sävar, Sweden. ${ }^{3}$ Silava, Latvia. ${ }^{4}$ Finnish Forest Research Institute, Haapastensyrjä, Finland. ${ }^{5}$ Finnish Forest Research Institute, Punkaharju, Finland.}

Published: 13 September 2011

doi:10.1186/1753-6561-5-S7-P129

Cite this article as: Högberg et al:: Practical testing of Scots pine cutting propagation - a joint Metla-Skogforsk-Silava project. BMC Proceedings 2011 5(Suppl 7):P129.

* Correspondence: tuija.aronen@metla.fi

${ }^{5}$ Finnish Forest Research Institute, Punkaharju, Finland

Full list of author information is available at the end of the article

(c) 2011 Högberg et al; licensee BioMed Central Ltd. This is an open access article distributed under the terms of the Creative Commons Attribution License (http://creativecommons.org/licenses/by/2.0), which permits unrestricted use, distribution, and reproduction in any medium, provided the original work is properly cited. 